\title{
PENGARUH SUBSTITUSI TEPUNG KIMPUL (Xanthosomasagittifolium) TERHADAP TINGKAT PENGEMBANGAN DAN DAYA TERIMA BOLU
}

\author{
Faresia Milda Kumara, Eni Purwani \\ Progam Studi Ilmu Gizi, Fakultas Ilmu Kesehatan Universitas Muhammadiyah Surakarta \\ onemilda@gmail.com
}

\begin{abstract}
Utilization of tubers in Indonesia is still low among others is the tannia (Xanthosoma sagittifolium). One way of processing the tannia so that it can be utilized into various food products is processed into flour. Flour can be utilized into various types of food, one of which is cake. Tannia does not have gluten protein content such as wheat flour that potentially affect the level of cake development and consumer acceptability. The purpose of this research is to know the effect of substitution of tannia flour on the level of the development and acceptibility of cake. The object used in this research is cake with $0 \%$ flavor substitution of tannia; $12.5 \% ; 25 \%$ and $37.5 \%$. The assessments include the level of spice development and the acceptability of color, flavor, taste, texture and overall. Panelists in this study as much as 33 panelists. The data analysis of cake substitution starch substitution was done using one way Anova test, while for the received power analysis using one way Anova test and Duncan test. The best cake development rate is cake with $12.5 \%$ tannia flour substitution with an average of $88.56 \%$ followed by $25 \%$ substitution with an average of $85.82 \%$. In the overall power-grab test the panelists favored the cake without substitution of tannia flour and followed by a $12.5 \%$ tannia flour substitution cake. There is no effect of substitution of tannia flour on cake development rate with $p$ value $=0,058$, and there is effect of substitution of tannia flour to cake color with $p$ value $=0.000$.
\end{abstract}

Keywords: Tannia flour, Level of development, Acceptibility, Cake. 


\section{PENDAHULUAN}

Cake adalah salah satu jenis makanan yang populer saat ini. Penggunaan nama cake dalam bahan pangan terkadang sama dengan penyebutan bolu. Bolu merupakan produk bakery yang terbuat dari tepung terigu, gula, lemak dan telur (Sunaryo, 1985). Bolu dapat diolah dengan beberapa cara seperti dikukus atau dipanggang dengan menggunakan oven.

Menurut Kementrian Pertanian Direktorat Jenderal Tanaman Pangan menyebutkan saat ini Indonesia merupakan Negara importer gandum peringkat tiga besar di dunia dengan total mencapai 7,4 juta ton pada tahun 2015 dan cenderung meningkat pada setiap tahunnya. Hal ini dapat berdampak pada ketahanan pangan nasional dan mengakibatkan ketergantungan masyarakat akan konsumsi bahan makanan dari luar negeri, sehingga perlu pemanfaatan pangan lokal Indonesia seperti berbagai macam jenis buah, serealia, sagu maupun umbi-umbian.

Umbi-umbian merupakan salah satu jenis tumbuhan yang memiliki banyak nilai guna. Umbi-umbian merupakan bahan sumber karbohidrat terutama pati dan dapat dimanfaatkan sebagai bahan dasar industri untuk menghasilkan produk komersial seperti makanan (Priyadi dan Silawati, 2004). Beberapa contoh sumber karbohidrat yang termasuk dalam jenis umbi-umbian antara lain kentang, singkong, uwi, gembili, sente, cantel dan talas (Astawan, 2004).

Talas adalah salah satu jenis umbi yang belum dimanfaatkan secara maksimal dalam pengolahannya. Di Indonesia, khususnya Jawa Tengah terdapat berbagai macam jenis talas dan salah satu jenis yang mudah di jumpai adalah talas kimpul. Talas ini memiliki nama ilmiah yaitu Xanthosoma sagittifolium. Komponen terbesar yang terdapat pada kimpul adalah karbohidrat (Ayu, 2004). Keunggulan lain yang terdapat pada kimpul adalah kandungan indeks glikemik yang tergolong rendah yaitu 54 sehingga dapat dikonsumsi oleh penderita Diabetes Mellitus.

Kimpul selama ini pemanfaatannya masih terbatas seperti direbus, dikukus, digoreng atau dibuat keripik. Kimpul memiliki sifat atau karakteristik yaitu tidak mempunyai rasa manis, daya serap air tinggi, dapat membentuk gel dalam air panas sehingga bersifat kental (Prihatiningrum, 2012). Kimpul dapat dibuat produk makan misalnya produk kue, biskuit dan lain-lain. pada pembuatan produk pangan agar dapat tercampur dengan homogen, perlu diolah menjadi tepung. Menurut Jatmiko, dkk (2013) kimpul memiliki kadar air yang tinggi sehingga apabila tidak diolah menjadi tepung, maka dapat menyebabkan adonan kurang padat dan sulit dibentuk. 
Berdasarkan penelitian yang dilakukan oleh Indrasti (2004) dengan tepung kimpul yang dijadikan bahan pengganti dalam pembuatan cookies, diketahui kandungan karbohidrat pada tepung kimpul yaitu sebesar 92,06\% ( $\%$ berat kering), lemak 0,92\% (\% berat kering), protein 4,88\% (\% berat kering) dan energi 359,56 kkal per 100 gram tepung kimpul.

Tingkat pengembangan bolu merupakan kemampuan bolu mengalami pertambahan ukuran setelah proses pengukusan atau pengovenan (Subagjo, 2007). Pengembangan bolu juga tergantung pada kocokan telur, selain itu gluten yang terkandung dalam protein tepung terigu secara tidak langsung mempengaruhi tingkat pengembangan (Suryani, 2000).

\section{METODE}

Penelitian ini merupakan penelitian eksperimental. Produk yang dibuat adalah bolu dengan substitusi tepung kimpul dengan 4 perlakuan yaitu bolu yang disubstitusi tepung kimpul $0 \% ; 12,5 \% ; 25 \% ; 37,5 \%$ dan kemudian diukur tingkat pengembangan dan daya terimanya. Pembuatan bolu dilakukan dengan mencampur seluruh bahan (tepung kimpul, tepung terigu, telur, gula pasir, margarin yang telah dilelehkan dan ovalet) dan dipanggang dalam oven dengan suhu $150^{\circ} \mathrm{C}$ selama 30 menit. Bolu dengan 4 perlakuan yaitu bolu yang disubstitusi tepung kimpul $0 \% ; 12,5 \% ; 25 \% ; 37,5 \%$ masing-masing dilakukan pengulangan sebanyak 3 kali sehingga total proses pembuatan bolu adalah 12 kali. Komposisi dan jumlah bahan dalam pembuatan bolu dapat dilihat pada tabel 1:

Tabel 1

\section{Komposisi Bahan dalam Pembuatan Bolu yang Disubstitusi Tepung} Kimpul

\begin{tabular}{lllllll}
\hline Perlakuan & $\begin{array}{l}\text { Tepung } \\
\text { Kimpul } \\
(\mathrm{g})\end{array}$ & $\begin{array}{l}\text { Tepung } \\
\text { Terigu } \\
(\mathrm{g})\end{array}$ & $\begin{array}{l}\text { Telur } \\
\text { Ayam } \\
(\mathrm{g})\end{array}$ & $\begin{array}{l}\text { Gula } \\
\text { Pasir } \\
(\mathrm{g})\end{array}$ & $\begin{array}{l}\text { Margarin } \\
(\mathrm{g})\end{array}$ & $\begin{array}{l}\text { Ovalet } \\
(\mathrm{g})\end{array}$ \\
\hline A & 0 & 100 & 55 & 80 & 100 & 5 \\
$\mathrm{~B}$ & 12,5 & 87,5 & 55 & 80 & 100 & 5 \\
$\mathrm{C}$ & 25 & 75 & 55 & 80 & 100 & 5 \\
$\mathrm{D}$ & 37,5 & 62,5 & 55 & 80 & 100 & 5 \\
\hline
\end{tabular}

Hasil substitusi ini didapatkan dari penelitian pendahuluan yang digunakan sebagai acuan. Pada penelitian pendahuluan bolu yang diujikan adalah bolu yang disubstitusi tepung kimpul 25\% dan 50\% kepada 15 panelis. Sebagian besar panelis memilih bolu yang disubstitusi tepung kimpul 25\% 
sebagai bolu yang lebih disukai. Berdasarkan hasil tersebut didapatkan hasil substitusi untuk penelitian utama. Panelis yang digunakan dalam penelitian utama sejumlah 33 panelis agak terlatih yaitu mahasiswa gizi Universitas Muhammadiyah Surakarta yang akan melakukan uji kesukaan daya terima meliputi warna, aroma, rasa, tekstur dan keseluruhan pada lembar formulir uji kesukaan. Skor pada penilaian terbagi menjadi 5 yaitu $5=$ sangat suka, $4=$ suka, 3=agak suka, 2=tidak suka, 1=sangat tidak suka. Pada uji tingkat pengembangan bolu diukur tinggi sebelum dan sesudah proses pemanggangan. Pengukuran tinggi adonan menggunakan dengan tusuk gigi dan penggaris.

Pengukuran melalui 3 titik yang berbeda yaitu titik tertinggi, titik tengah dan titik terendah sehingga diketahui rata-rata tingginya dan kemudian tingkat pengembangan dapat diketahui dengan rumus yaitu:

$\%$ pengembangan $=\frac{B-A}{A} \times 100 \%$

Keterangan:

A : Tinggi adonan sebelum pemanggangan

B : Tinggi adonan setelah pemanggangan.

\section{HASIL DAN PEMBAHASAN}

Bolu pada penelitian ini adalah bolu panggang dengan penambahan substitusi tepung kimpul sebesar $0 \% ; 12,5 \% ; 25 \%$ dan 37,5\%. Besar persentase jumlah substitusi tepung kimpul yang digunakan dalam penelitian utama didapatkan dari hasil penelitian pendahuluan yaitu bolu dengan substitusi tepung kimpul sebesar 25\% dan 50\%. Penelitian pendahuluan meliputi daya terima meliputi kategori warna, aroma, rasa, tekstur dan keseluruhan. Berdasarkan uji daya terima pada penelitian pendahuluan didapatkan hasil panelis cenderung lebih menyukai bolu dengan substitusi tepung kimpul 25\%.

Variasi penambahan tepung kimpul dalam pembuatan bolu dilakukan untuk mengetahui pengaruh penambahan tepung kimpul terhadap tingkat pengembangan dan daya terima bolu. Tingkat pengembangan berdasarkan pengukuran tinggi adonan dan daya terima berdasarkan uji kesukaan oleh panelis.

\section{Tingkat Pengembangan}

Hasil analisis menunjukkan penambahan tepung kimpul tidak memberikan pengaruh nyata terhadap tingkat pengembangan yang dihasilkan. Rata-rata tingkat pengembangan pada bolu yang disubstitusi tepung kimpul dapat dilihat pada Tabel 2: 


\section{Tabel 2}

\section{Rata-Rata Tingkat Pengembangan Bolu Menggunakan Substitusi Tepung Kimpul yang Berbeda}

\begin{tabular}{ccccc}
\hline \multirow{2}{*}{$\begin{array}{c}\text { Substitusi tepung } \\
\text { kimpul }\end{array}$} & \multicolumn{3}{c}{ Hasil Ulangan Analisis (\%) } & Rata-rata SD \\
\cline { 2 - 4 } & $\mathrm{I}$ & $\mathrm{II}$ & $\mathrm{III}$ & \\
\hline $0 \%$ & 79,16 & 54,47 & 75,08 & $69,57 \pm 13,23$ \\
$12,5 \%$ & 81,81 & 77,96 & 105,93 & $88,56 \pm 15,15$ \\
$25 \%$ & 72,72 & 80,86 & 103,88 & $85,82 \pm 16,16$ \\
$37,5 \%$ & 49,63 & 60,08 & 60,18 & $56,63 \pm 6,06$ \\
\hline Nilai p & \multicolumn{4}{c}{0,058} \\
\hline
\end{tabular}

Tabel 2 menunjukkan bahwa hasil rata-rata tingkat pengembangan pada bolu dengan besar substitusi 12,5\% menghasilkan tingkat pengembangan yang paling tinggi yaitu 88,56\% dan diikuti dengan bolu kontrol tanpa substitusi tepung kimpul. Bolu dengan tingkat pengembangan terendah adalah bolu dengan jumlah substitusi tepung kimpul paling besar yaitu 37,5\% dengan hasil rata-rata tingkat pengembangan 56,63\%. Masing-masing perlakuan menghasilkan tingkat pengembangan yang berbeda yang disebabkan oleh jumlah substitusi tepung yang berbeda pada setiap perlakuan.

Hasil analisis statistik mengenai pengaruh bolu dengan substitusi tepung kimpul menggunakan uji Anova diperoleh nilai p >0,05 yaitu 0,058. Hal ini menunjukkan tidak ada pengaruh substitusi tepung kimpul terhadap tingkat pengembangan bolu. Tidak ada pengaruh pada tingkat pengembangan bolu subtitusi tepung kimpul ini dikarenakan tidak ada persentase tepung kimpul yang mempengaruhi. Ada kecenderungan semakin tinggi substitusi tepung kimpul maka tingkat pengembangan akan menurun. Namun secara statistik tidak signifikan berbeda antara bolu kontrol dengan bolu substitusi tepung kimpul 12,5\% dimana tingkat pengembangan tertinggi adalah pada bolu dengan substitusi tepung kimpul 12,5\%. Hal ini tidak sesuai dengan hasil penelitian oleh S. Basuki E.K, dkk (2013) semakin banyak substitusi tepung terigu maka dapat menyebabkan jumlah gluten dalam adonan akan semakin meningkat, sehingga akan meningkatkan kemampuan adonan dalam menahan gas $\mathrm{CO}_{2}$ yang menyebabkan terjadinya peningkatan volume pengembangan bolu. Menurut Subarna (1992) gluten memiliki sifat fisik yang elastis dan ekstensibel sehingga memungkinkan adonan dapat menggelembung seperti balon. Hal inilah yang memungkinkan produk roti mempunyai struktur berongga yang seragam dan halus. 


\section{Daya Terima Bolu}

Berdasarkan Berdasarkan hasil uji kenormalan, data berdistribusi tidak normal sehingga dilanjutkan dengan uji One $W$ ay Anova. Pada tabel 3 terdapat hasil nilai $\mathrm{p}$ pengaruh substitusi tepung kimpul terhadap daya terima panelis meliputi warna, aroma, rasa, tekstur dan keseluruhan.

Tabel 3.

Hasil Uji Daya Terima Panelis terhadap Bolu

\begin{tabular}{cc}
\hline Daya Terima & Nilai p \\
\hline Warna & 0,000 \\
Aroma & 0,133 \\
Rasa & 0,802 \\
Tekstur & 0,197 \\
Keseluruhan & 0,622 \\
\hline
\end{tabular}

Pada tabel tersebut menunjukkan adanya pengaruh substitusi tepung kimpul terhadap warna bolu dengan nilai signifikansi $\mathrm{p}<0,05$ yaitu 0,000 sehingga dilanjutkan pada uji Duncan. Pada daya terima aroma, rasa, tekstur dan keseluruhan bolu tidak terdapat pengaruh substitusi tepung kimpul.

Tabel 4.

Hasil Uji Duncan pada Daya Terima Warna

\begin{tabular}{ll}
\hline Substitusi Tepung Kimpul & Warna \\
\hline $0 \%$ & $4,09^{\mathrm{c}}$ \\
$12,5 \%$ & $3,39^{\mathrm{b}}$ \\
$25 \%$ & $2,87^{\mathrm{a}}$ \\
$37,5 \%$ & $2,63^{\mathrm{a}}$ \\
\hline Nilai p & 0,000 \\
\hline
\end{tabular}

Keterangan : Notasi huruf yang berbeda menunjukkan

beda nyata pada hasil analisis uji Duncan.

Berdasarkan hasil uji Anova One Way, daya terima warna terhadap bolu dengan substitusi tepung kimpul yang berbeda memiliki nilai signifikasi $\mathrm{p}<0,05$ yaitu 0,000 maka ada pengaruh substitusi tepung kimpul terhadap warna bolu sehingga dilanjutkan dengan uji Duncan. Pada hasil uji Duncan diketahui terdapat beda nyata pada substitusi $0 \%$ dengan substitusi $12,5 \% ; 25 \% ; 37,5 \%$. Berdasarkan uji daya terima pada 33 panelis, daya terima warna bolu yang paling disukai adalah bolu kontrol tanpa substitusi tepung kimpul diikuti bolu dengan substitusi tepung kimpul 12,5\%, dan daya terima warna paling rendah adalah bolu dengan substitusi tepung kimpul 37,5\%. Hal ini sesuai dengan penelitian Prihatiningrum (2012) yaitu pada tepung kimpul mengandung senyawa saponin (glikosida alamiah) dan apabila mengalami pemanasan akan menyebabkan warna coklat. Warna coklat yang timbul juga dapat dipicu oleh 
reaksi Maillard karena adanya reaksi yang terjadi antara gugus asam amino bebas dengan gugus karbonil dari suatu karbohidrat jika keduanya dipanaskan (Yokotsuko, 1986).

Berdasarkan hasil uji One $W$ ay Anova, daya terima aroma terhadap bolu dengan substitusi tepung kimpul memiliki nilai signifikansi $\mathrm{p}>0,05$ yaitu 0,133 maka tidak ada pengaruh substitusi tepung kimpul terhadap aroma bolu. Berdasarkan hasil uji daya terima oleh 33 panelis, daya terima aroma paling tinggi adalah pada bolu kontrol dengan tanpa substitusi tepung kimpul diikuti oleh bolu dengan substitusi tepung kimpul 12,5\%, dan hasil terendah pada bolu dengan substitusi tepung kimpul terbesar yaitu pada substitusi 37,5\%. Hal ini sesuai dengan pendapat Prihatiningrum (2012), bahwa hal ini dapat disebabkan karena tepung kimpul memiliki karakteristik aroma yang langu sehingga persentase substitusi tepung kimpul yang semakin besar akan mempengaruhi panelis dalam memberikan penilaian daya terima terhadap aroma bolu.

Berdasarkan uji One Way Anova, daya terima rasa terhadap bolu memiliki nilai signifikansi $\mathrm{p}>0,05$ yaitu 0,802 sehingga tidak ada pengaruh substitusi tepung kimpul terhadap rasa bolu. Berdasarkan hasil uji daya terima oleh 33 panelis daya terima rasa paling tinggi ditunjukkan oleh bolu tanpa substitusi tepung kimpul diikuti oleh bolu dengan substitusi tepung kimpul $12,5 \%$, sedangkan daya terima paling rendah ditunjukkan oleh bolu dengan substitusi tepung kimpul 25\% dan 37,5\%. Hal ini sesuai dengan hasil penelitian utama dimana bolu kontrol memiliki respon yang lebih baik dari segi rasa dibandingkan dengan bolu dengan substitusi tepung kimpul karena dipengaruhi bau yang langu dari kimpul dan berpengaruh dalam penilaian rasa.

Berdasarkan hasil uji One Way Anova, diketahui nilai signifikansi daya terima tekstur adalah $\mathrm{p}>0,05$ yaitu 0,197 maka tidak ada pengaruh substitusi tepung kimpul terhadap daya terima tekstur bolu. Berdasarkan hasil uji daya terima terhadap 33 panelis menunjukkan bahwa bolu dengan substitusi tepung kimpul paling besar yaitu 37,5\% memiliki daya terima yang paling rendah dibandingkan dengan bolu kontrol yang tanpa menggunakan substitusi tepung kimpul yang memiliki daya terima paling tinggi diikuti oleh bolu dengan substitusi tepung kimpul 12,5\%. Hal ini sesuai dengan Rafika dkk (2012) bahwa tingkat kesukaan panelis terhadap tekstur dipengaruhi oleh tingkat kepadatan dan kerapuhan bolu. Bolu dengan substitusi tepung kimpul paling besar yaitu 37,5\% tidak disukai panelis karena teksturnya yang padat dan bantet serta lebih rapuh, sehingga bolu yang paling disukai oleh panelis berdasarkan hasil penelitian utama adalah bolu kontrol tanpa substitusi tepung kimpul. 
Berdasarkan hasil uji One Way Anova, didapatkan hasil nilai signifikansi kesukaan keseluruhan $\mathrm{p}>0,05$ yaitu 0,662 maka tidak ada pengaruh substitusi tepung kimpul terhadap kesukaan keseluruhan bolu. Berdasarkan hasil uji daya terima terhadap 33 panelis menunjukkan bolu tanpa substitusi tepung kimpul memiliki nilai kesukaan keseluruhan yang paling tinggi dan bolu dengan substitusi tepung kimpul 37,5\% memiliki hasil kesukaan keseluruhan yang paling rendah. Hal ini sesuai dengan daya terima pada warna, aroma, rasa dan tekstur yang memiliki nilai daya terima paling tinggi pada bolu tanpa substitusi (kontrol) diikuti oleh bolu dengan substitusi tepung kimpul 12,5\% dan paling rendah pada substitusi 37,5\%. Hal tersebut dapat dipengaruhi karena panelis belum terbiasa dengan substitusi tepung selain tepung terigu pada pembuatan produk olahan roti yang menyebabkan warna menjadi lebih gelap, memiliki aroma yang langu dan tekstur yang padat dan bantet sehingga bolu kontrol dengan substitusi tepung kimpul $0 \%$ mendapat respon paling baik.

\section{KESIMPULAN}

Kesimpulan dari penelitian ini tingkat pengembangan paling tinggi ditunjukan oleh bolu yang disubstitusi tepung kimpul 12,5\% dengan nilai ratarata tingkat pengembangan $88,56 \%$ dan tingkat pengembangan paling rendah ditunjukan oleh bolu yang disubstitusi tepung kimpul 37,5\% dengan nilai ratarata tingkat pengembangan 56,63\%. Tidak ada pengaruh substitusi tepung kimpul pada bolu terhadap tingkat pengembangan bolu dengan nilai signifikansi $\mathrm{p}>0,05$ yaitu 0,058 . Ada pengaruh besar substitusi tepung kimpul terhadap warna bolu dengan nilai signifikansi warna $(p=0,000)$, dan tidak ada pengaruh besar substitusi kimpul terhadap aroma, rasa, tekstur dan kesukaan keseluruhan dengan nilai signifikansi $p>0,05$ yaitu aroma $(p=0,133)$, rasa $(p=0,802)$, tekstur $(p=0,197)$, dan keseluruhan $(p=0,662)$. Berdasarkan persentase secara keseluruhan panelis cenderung menyukai bolu tanpa tepung kimpul (kontrol), dan pada bolu yang disubstitusi tepung kimpul hasil terbaik adalah pada bolu yang disubstitusi tepung kimpul 12,5\%.

\section{DAFTAR PUSTAKA}

Astawan M, dan Wresdiyati, T. 2004. Diet Sehat dengan Makanan Berserat. Tiga Serangkai Pustaka Mandiri. Solo. Hal: 44-45.

Ayu., Disafitri Candra, et al. 2014. Pengaruh Suhu Blansing dan Lama Perendamanterhadap Sifat Fisik Kimia Tepung Kimpul (Xanthosoma Sagittifolium). Jurnal Pangan dan Agroindustri Jurusan Teknologi Hasil Pertanian Fakultas Teknologi Pertanian Universitas Brawijaya Malang. Vol.2, No.2, Hal 110-120. 
Indrasti D. 2004. Pemanfaatan Tepung Talas Belitung dalam Pembuatan Cookies. (Skripsi). Bogor. Fakultas Teknologi Pertanian, Institut Pertanian Bogor.

Jatmiko, GP., dan Estiasih, T. 2014. Mie dari umbi Kimpul (Xanthosoma sagittifolium) :Kajian Pustaka. Jurnal Pangan dan Agroindustri. Vol. 2 No. $2: 127-134$.

Koswara S. 2013. Teknik Pengolahan Umbi-Umbian: Pengolahan Umbi Talas. Modul. Bogor.

Mutmainah. 2008. Daya Terima Makanan dan Tingkat Konsumsi Energi-Protein Pasien Rawat Inap Penderita Penyakit Dalam di Rumah Sakit Dr.H.Marzoeki Mahdi. Skripsi. Program Sarjana Gizi Masyarakat Dan Sumberdaya Keluarga Fakultas Pertanian Institut Pertanian Bogor. Bogor.

Prihatiningrum. 2012. Pengaruh komposit tepung kimpul dan tepung terigu terhadap kualitas cookies semprit. Food Science and Culinary Education Jurnal 1 (1) : 6-12.

Priyadi A dan Silawati T. 2004.Sains Biologi Kelas 1 SMA. Jakarta: Yudhistira.

Rafika T, Nurjanah N, dan Hidayati L. 2012. Sifat organoleptik substitusi tepung kimpul dalam pembuatan cake. Jurnal Teknologi dan Kejuruan 35(2): 213-222.

S. Basuki E K, Yulistiani R, Hidayat R. 2013. Kajian Substitusi Tepung Tapioka dan Penambahan Gliserol Monostearat pada Pembuatan Roti Tawar. Hal: 131134.

Sunaryo, E. 1985. Pengolahan Produk Serealia dan Biji-Bijian Jurusan Teknologi Pangan dan Gizi. IPB, Bogor.

Subagjo, Adjab. 2007. Manajemen Pengolahan Kue dan Roti. Yogyakarta. Graha Ilmu.

Subarna, 1992. Baking Technology. Pusat Antar Universitas Pangan dan Gizi. IPB, Bogor.

Suryani, I. 2000. Pemanfaatan Tepung Cantel Sebagai Bahan Pembuatan Cake. Pusat Pendidikan Tenaga Kesehatan. Yogyakarta.

Yokotsuka T. 1986. Soy Sauce Biochemistry. Adv. Food. Res. (30). 195-329. 